\title{
Regioselectivity of Electrophilic Attack on 4-Methyl-1-thioxo- 1,2,4,5-tetrahydro[1,2,4] triazolo[4,3-a]quinazolin-5-one. Part 1: Reactions at the Sulfur Atom
}

\author{
Walid Fathalla ${ }^{1}$, Michal Čajan ${ }^{1,2}$ and Pavel Pazdera*1 \\ ${ }^{1}$ Department of Organic Chemistry, Faculty of Science, Masaryk University, Brno, Czech \\ Republic. Tel.: +420 5 41129305, Fax: +420 541211214. \\ ${ }^{2}$ National Center for Biomolecular Research, Faculty of Science, Masaryk University, Brno, \\ Czech Republic.
}

*Author to whom correspondence should be addressed; E-mail: pazdera@chemi.muni.cz

Received: 16 July 2000; in revised form 21 May 2001 / Accepted: 23 May 2001 / Published: 31 May 2001

\begin{abstract}
The regioselectivity of the model compound 4-methyl-1-thioxo1,2,4,5-tetrahydro[1,2,4]triazolo[4,3-a]quinazolin-5-one (3) towards different electrophiles was studied. Compound 3 reacts with alkyl and aryl halides to give the corresponding $S$-substituted derivatives. The reaction of the model thioamide with acyl halides proceeds by the formation of kinetically controlled $S$-acyl derivatives followed by a transacylation reaction to give the $N^{2}$-acyl derivatives as thermodynamically controlled products. Theoretical DFT computational studies supported the explanation of these results. The synthesized compounds were characterized by FTIR, ${ }^{1} \mathrm{H}-\mathrm{NMR},{ }^{13} \mathrm{C}-\mathrm{NMR}$, and mass spectroscopy.
\end{abstract}

Keywords: Cyclic thioamides, regioselective reactions, 4-methyl-1-thioxo1,2,4,5-tetrahydro[1,2,4]triazolo[4,3-a]quinazolin-5-one, DFT computational studies. 


\section{Introduction}

The thioamide group is an interesting system for heterocyclic chemists because it can be used as a useful synthetic building bloc, and its regioselectivity towards different electrophiles gives the group of the great importance. The literature data show that in most cases of nucleophilic substitution of an alkyl halide on a thioamide system sulfur atom attack is favored [1], while very few examples are known where attack on the nitrogen atom is preferred [2]. The reaction of acyl halides with thioamides gave the $\mathrm{N}$-acyl derivatives $[3,4]$, while aromatic nucleophilic substitution of nitro aryl halides took place on the sulfur atom [5].

\section{Results and Discussion}

In this paper we report the results of a study of the regioselectivity of reactions of various electrophilic reagents (alkyl, acyl and activated aryl halides) with the thioamide moiety of the model compound 4-methyl-1-thioxo-1,2,4,5-tetrahydro[1,2,4]triazolo[4,3-a]quinazolin-5-one (3).

The theoretical DFT studies of the anion formed by deprotonation of $\mathbf{3}$ (Figures 1a-b; results are summarized in Tables $1-3$ ) show that the anionic form is completely planar thus conferring aromaticity to the whole system. On the other hand, the $\mathrm{C}(1)-\mathrm{N}(2)$ bond order value would suggest its double bond character, as could be expected for form 3a. However, the C(1) - S(11) bond order value is even larger, which indicates the delocalization of negative charge between the sulfur and nitrogen atoms. A residual bond order determined between the $\mathrm{H}(17)$ and $\mathrm{S}(11)$ atoms show the weak H-bond character of the interaction between them.

The results of the theoretical DFT studies gave a larger value for the HOMO coefficient $\mathrm{c}^{2}$ on sulfur than the same on N(2). Finally, the partial charge distributed on the sulfur atom is slightly higher than that on the nitrogen atom [6]. These results indicate that electrophilic attack on the sulfur atom might be preferred, in disagreement with literature data mentioned above.

These facts led us to focus our interest on controlled reactions involving only one of these two forms and to examine reaction of these two structural forms with different electrophiles. The problems faced are the elucidation of product structure if the reaction takes place either at the nitrogen or the sulfur atoms, or on both, the secondly, to give a satisfactory explanation to account for such a behavior.

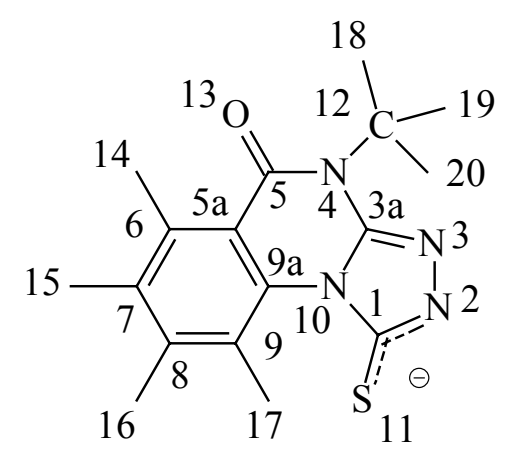

Figure 1a. Numbering of the model compound $\mathbf{3}$ - anion. 


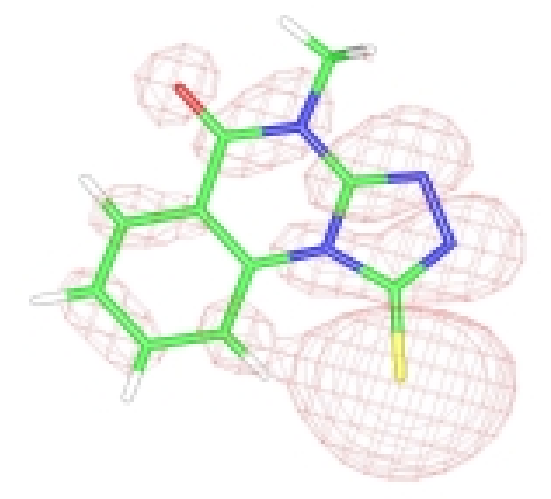

Figure1b. HOMO graphical representation of the anion form of 3 .

Table 1. The molecular orbital coefficient values of the anion form of $\mathbf{3}$.

\begin{tabular}{|c|c|c|c|c|c|c|c|}
\hline \multicolumn{9}{|c|}{ HOMO } & \multicolumn{4}{c|}{ LUMO } \\
\hline atom & orbital & coefficient c & $\mathrm{c}^{2}$ & atom & orbital & coefficient c & $\mathrm{c}^{2}$ \\
\hline $\mathrm{N} 2$ & $2 \mathrm{pz}$ & -0.2781 & 0.0740 & $\mathrm{~N} 2$ & $2 \mathrm{pz}$ & -0.0812 & 0.0066 \\
$\mathrm{C} 3 \mathrm{a}$ & $2 \mathrm{pz}$ & 0.1886 & 0.0355 & $\mathrm{C} 3 \mathrm{a}$ & $2 \mathrm{pz}$ & 0.0239 & 0.0005 \\
$\mathrm{~N} 3$ & $2 \mathrm{pz}$ & 0.1441 & 0.0207 & $\mathrm{~N} 3$ & $2 \mathrm{pz}$ & 0.0300 & 0.0009 \\
$\mathrm{~N} 4$ & $2 \mathrm{pz}$ & -0.1039 & 0.0108 & $\mathrm{~N} 4$ & $2 \mathrm{pz}$ & -0.1971 & 0.0388 \\
$\mathrm{C} 9$ & $2 \mathrm{pz}$ & 0.0326 & 0.0010 & $\mathrm{C} 9$ & $2 \mathrm{pz}$ & -0.1562 & 0.0244 \\
$\mathrm{C} 9 \mathrm{a}$ & $2 \mathrm{pz}$ & -0.0014 & 0 & $\mathrm{C} 9 \mathrm{a}$ & $2 \mathrm{pz}$ & -0.2029 & 0.0411 \\
$\mathrm{C} 5 \mathrm{a}$ & $2 \mathrm{pz}$ & 0.0300 & 0.0009 & $\mathrm{C} 5 \mathrm{a}$ & $2 \mathrm{pz}$ & 0.2396 & 0.0574 \\
$\mathrm{C} 6$ & $2 \mathrm{pz}$ & 0.0333 & 0.0011 & $\mathrm{C} 6$ & $2 \mathrm{pz}$ & -0.2304 & 0.0531 \\
$\mathrm{C} 5$ & $2 \mathrm{pz}$ & -0.0552 & 0.0030 & $\mathrm{C} 5$ & $2 \mathrm{pz}$ & 0.2674 & 0.0715 \\
$8 \mathrm{C}$ & $2 \mathrm{pz}$ & -0.0322 & 0.0010 & $8 \mathrm{C}$ & $2 \mathrm{pz}$ & 0.2948 & 0.0869 \\
$\mathrm{O} 13$ & $2 \mathrm{pz}$ & 0.0715 & 0.0051 & $\mathrm{O} 13$ & $2 \mathrm{pz}$ & -0.2179 & 0.0475 \\
$\mathrm{H} 17$ & $1 \mathrm{~s}$ & 0.0000 & 0 & $\mathrm{H} 17$ & $1 \mathrm{~s}$ & -0.0000 & 0 \\
& $2 \mathrm{~s}$ & -0.0000 & 0 & & $2 \mathrm{~s}$ & -0.0000 & 0 \\
$\mathrm{~S} 11$ & $2 \mathrm{pz}$ & -0.2070 & 0.0428 & $\mathrm{~S} 11$ & $2 \mathrm{pz}$ & -0.0078 & 0 \\
& $3 \mathrm{pz}$ & 0.5352 & 0.2864 & & $3 \mathrm{pz}$ & 0.0230 & 0.0005 \\
\hline
\end{tabular}

Table 2. The partial charge values of selected atoms in the anion form of $\mathbf{3}$.

\begin{tabular}{|c|cc|c|cc|c|cc|}
\hline & Mulliken & ESP & & Mulliken & ESP & & Mulliken & ESP \\
\hline $1 \mathrm{C}$ & 0.2998 & 0.2615 & $5 \mathrm{C}$ & 0.5793 & 0.5440 & $10 \mathrm{~N}$ & -0.6558 & -0.0286 \\
$2 \mathrm{~N}$ & -0.3620 & -0.3966 & $5 \mathrm{aC}$ & 0.0077 & 0.0651 & $11 \mathrm{~S}$ & -0.4943 & -0.6419 \\
$3 \mathrm{~N}$ & -0.4398 & -0.4141 & $7 \mathrm{C}$ & -0.1357 & -0.2638 & $12 \mathrm{C}$ & -0.3134 & -0.1919 \\
$3 \mathrm{aC}$ & 0.7242 & 0.5434 & $8 \mathrm{C}$ & -0.1481 & -0.0242 & $13 \mathrm{O}$ & -0.5631 & -0.5354 \\
$4 \mathrm{~N}$ & -0.5512 & -0.2757 & $9 \mathrm{aC}$ & 0.3345 & 0.1136 & $17 \mathrm{H}$ & 0.1947 & 0.1385 \\
\hline
\end{tabular}


Table 3. Bond orders of selected bonds in the anion form of $\mathbf{3}$.

\begin{tabular}{|cc|cc|cc|}
\hline S11-H17 & 0.1326 & N4-C3a & 1.0977 & C5-N4 & 1.1996 \\
C9a-N10 & 1.0707 & C3a-N10 & 1.2015 & C1-N2 & 1.6805 \\
C5a-C5 & 1.1157 & C3a-N3 & 1.8301 & C1-N10 & 0.9445 \\
C5-O13 & 1.8372 & N2-N3 & 1.0744 & C1-S11 & 2.0511 \\
\hline
\end{tabular}

Compound 3 was prepared by a series of reactions starting from the easily available 3-methyl2-sulfanyl-3,4-dihydro-4-quinazolinone 1 [7]. Hydrazinolysis of this starting quinazoline afforded the hydrazine derivative 2 that subsequently reacts with carbon disulfide to give the desired product 3 [8].

The triazoloquinazoline derivative displays an interesting tautomeric equilibrium between the thiol (3a) and thione (3b) forms. This was proven by ${ }^{1} \mathrm{H}-\mathrm{NMR}$ spectroscopy $\left(\left(\mathrm{CD}_{3}\right)_{2} \mathrm{SO}\right)$, which shows a mixture of these two forms in a ratio of about 1:1 thiol $\mathbf{3 a}$ to thione $\mathbf{3} \mathbf{b}$ forms.<smiles>Cn1c(S)nc2ccccc2c1=O</smiles>

1<smiles>Cn1c(=O)c2ccccc2n2c(S)nnc12</smiles>

$3 \mathbf{a}$<smiles>Cn1c(NN)nc2ccccc2c1=O</smiles>

2<smiles>Cn1c(=O)c2ccccc2n2c(=S)[nH]nc12</smiles>

3b
a: $\mathrm{NH}_{2} \mathrm{NH}_{2}$, butanol, $118^{\circ} \mathrm{C}, 18 \mathrm{~h}$.
b: $\mathrm{CS}_{2}$, ethanol, $\mathrm{KOH}, 70^{\circ} \mathrm{C}, 6 \mathrm{~h}$.

Scheme 1. Synthesis of the model compound 3 
<smiles></smiles>

7<smiles>Cn1c(=O)c2ccccc2n2c(Sc3ccc([N+](=O)[O-])cc3[N+](=O)[O-])nnc12</smiles>

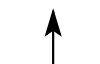

(1)
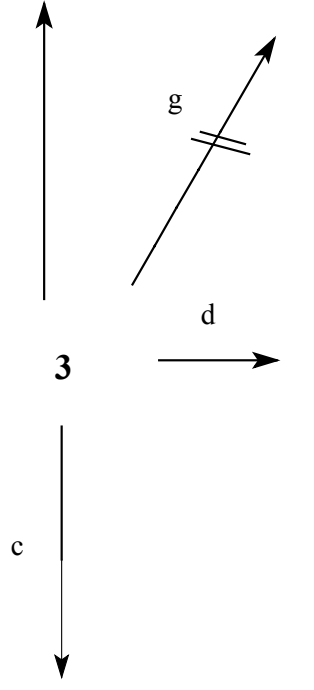

$\mathrm{R}=\mathrm{CN}, \mathrm{COOEt} \mathbf{5}$

8

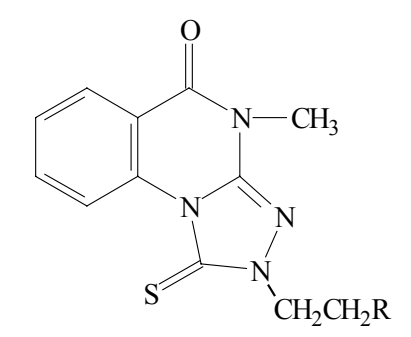

5<smiles>[R]C([R])Sc1nnc2n(C)c(=O)c3ccccc3n12</smiles>

\begin{tabular}{|c|c|c|}
\hline $\mathbf{R}$ & $\mathbf{R}$ & $\mathbf{X}$ \\
\hline $\mathrm{COOH}, \mathrm{COOMe}, \mathrm{CN}, \mathrm{CH}_{2} \mathrm{COOH}, \mathrm{CONH}_{2}$, & $\mathrm{H}$ & $\mathrm{Cl}$ \\
\hline $\mathrm{COPh}, \mathrm{COPh}-\mathrm{p}-\mathrm{Cl}, \mathrm{COPh}-\mathrm{p}-\mathrm{OCH}_{3}, \mathrm{Ph}, \mathrm{CH}=\mathrm{CH}_{2}$ & $\mathrm{H}$ & $\mathrm{Br}$ \\
\hline $\mathrm{H}$ & $\mathrm{H}$ & $\mathrm{I}$ \\
\hline $\mathrm{CH}_{3}$ & $\mathrm{CH}_{3}$ & $\mathrm{I}$ \\
\hline
\end{tabular}

c: $X C H R R ', N\left(\mathrm{C}_{2} \mathrm{H}_{5}\right)_{3}$, ethanol, $78^{\circ} \mathrm{C}, 4-6 \mathrm{~h}$.

d: $\mathrm{ClCH}_{2} \mathrm{CH}_{2} \mathrm{R}, \mathrm{NaOH}$, ethanol, $78^{\circ} \mathrm{C}, 6 \mathrm{~h}$.

e: 2,4-dinitrochlorobenzene, $\mathrm{N}\left(\mathrm{C}_{2} \mathrm{H}_{5}\right)_{3}$, ethanol, $78^{\circ} \mathrm{C}, 15 \mathrm{~min}$.

f: $\mathrm{ClCOR}, \mathrm{N}\left(\mathrm{C}_{2} \mathrm{H}_{5}\right)_{3}$, benzene, $80^{\circ} \mathrm{C}, 15 \mathrm{~min}$.

g: pyridine, $\mathrm{PhCOCl}, 80^{\circ} \mathrm{C}, 6 \mathrm{~h}$.

h: $\mathrm{CHCl}_{3}, 50^{\circ} \mathrm{C}, 4 \mathrm{~h}$.

Scheme 2. Alkylation, acylation and arylation reactions of the model compound 3. 
The ambident nucleophile 3 reacts with alkyl halides in several solvents (absolute ethyl alcohol, $95 \%$ ethyl alcohol and benzene) under basic conditions $\left(\mathrm{K}_{2} \mathrm{CO}_{3}, \mathrm{NEt}_{3}\right.$ to produce the $S$-substituted products 4 via an $\mathrm{S}_{\mathrm{N}} 2$ reaction mechanism with almost all the alkyl halides used. On the other hand, when either 3-chloropropanenitrile and methyl-3-chloropropanoate were used, the reaction gave the $N(2)$-substituted products 5.

We might expect that the reaction would take place on the softer side of the ambident nucleophile (the sulfur atom) because of the soft character of the alkyl halides [9]. Indeed, the reactions of alkyl halides with triazoloquinazoline in ethanol and triethylamine generally took place at the sulfur atom. The reaction is can be explained by an interaction between the HOMO of the nucleophile and the LUMO of the electrophile to produce the $S$-attack. The reaction involves the attack of the nucleophile at the carbon atom of the electrophile to give the $\mathrm{S}_{\mathrm{N}} 2$ transition state (the carbon atom is coordinated to three substituents and partially bonded to both the leaving group (halogen atom) and the ambident nucleophile, then the halide as a leaving group is expelled and the carbon atom regains tetra coordination. The ordering of $\mathrm{S}_{\mathrm{N}} 2$ transition state inhibits the attack at the nitrogen atom due to the steric effects caused the bulky rigid part of the planar triazole side.

The alternative pathway is the formation of this transition state at the sulfur atom, which has several advantages compared to the former nitrogen attack. The sulfur atom attack is preferred due to sterically free access, higher partial charge and better polarizability due to its $3 p$ orbital.

Several attempts were made to carry out the reaction of 3-chloropropanenitrile and methyl-3chloropropanoate with 3 under different reaction conditions. It was found the reaction only took place in ethyl alcohol and in the presence of sodium hydroxide as a base to produce the $N(2)$ substituted alkyl derivatives 5. The reagents 3-chloropropanenitrile and methyl-3-chloropropanoate underwent an elimination reaction to give acrylonitrile or methyl acrylate in situ, respectively. The presence of the planar $\mathrm{C}=\mathrm{C}$ double bond conjugated with the electron withdrawing nitrile or methoxycarbonyl group produced an electron deficiency on the $\mathrm{C} 3$ carbon atom, consequently giving a partial positive charge on this atom. Interaction between both planar acrylic and triazole systems is free of steric hindrance, too. On the other hand, the energy of LUMO in both acrylic acid functional derivatives is decreased and the coupling of activated $\mathrm{C}=\mathrm{C}$ double bond takes place at the nitrogen atom. The reaction is produced by strong coulombic attraction at the hard part of the ambident nucleophile to finally produce the $N$-substituted alkyl derivatives $\mathbf{5}$. The same products $\mathbf{5}$ are formed when the ambident nucleophile reacts with acrylonitrile and methyl acrylate. This gave more evidence for the involvement of methyl acrylate and acrylonitrile in the course of the reaction $[6]$.

The reaction of $\mathbf{3}$ with 3-chloropropanoic acid might show some similarity to the proceeding reactions, since we might expect the elimination of hydrogen chloride followed by reaction with $\mathbf{3}$ to give the $N$-alkyl derivative. Our result was completely different in this case, yielding the $S$-alkyl derivative 4. The same result was obtained 3-bromopropanoic acids were used. This is attributed to the weak electron withdrawing ability of the carboxylate anion compared to both the nitrile and ester group in the former reaction. The previously mentioned factor facilitates the elimination reaction in the case of 3-chloropropanenitrile and methyl-3-chloropropanoate, and is not effective in the case of the salts of both 3-chloro- and 3-bromopropanoic acid. It is noteworthy that acrylic 
acid gave no reaction with $\mathbf{3}$ under various reaction conditions [6], which indicates that alkylation with 3-chloropropanoic acids only leads to the $S$-substituted alkyl derivatives.

The reaction of the triazolo derivative 3 with the 2,4-dinitrochlorobenzene in the presence of triethylamine gave the $S$-aryl product $\mathbf{6}$ by a nucleophilic aromatic substitution reaction via formation of Meisenheimer's complex. As described the reaction seems to be similar to the $\mathrm{S}_{\mathrm{N}} 2$ reaction and this explains the formation of the $S$-substituted aryl derivative.

The reaction of triazoloquinazoline 3 with pivaloyl chloride or ethyl chloroformate gave a mixture of the $S$ - (minor) 7 and $N$-acyl (major) 8 products after 15 min reflux. Extending the reaction time resulted in the formation of only the $N$-acyl product 8 . On the other hand the reaction of 3 with benzoyl chloride gave only the $N$-acyl derivative 8 . It is noteworthy that the acylation reaction using the acyl halides in the presence of pyridine as a solvent and base gave an acyl pyridinium cation which is known as a hard electrophile, so applying this reaction condition to our ambident nucleophile and the acyl halides might lead to the sole formation of the $N$-acyl derivative 8. In fact no result was observed under the former reaction conditions, which confirms that the $N$ acyl derivative is not directly formed due to steric effects. We conclude that the reaction of the acyl halides in presence of benzene and triethylamine is a kinetically controlled reaction and results in formation of the $S$-acyl product 7 via orbital-interactions. This product undergoes a trans-acylation reaction to give the thermodynamically controlled $\mathrm{N}$-acyl derivative $\mathbf{8}$ under the effect of prolonged reaction times or by heating the reaction mixtures. The trans-acylation reaction is proceeded by the formation of the acyl carbocation formed under elevated temperature by the $A_{B} 1$ mechanism, and is capable of attacking the nitrogen atom to produce the $N$-substituted acyl derivative.

The elucidation of $N$ - and $S$-substituted derivative structures was performed using several analytical techniques: the IR spectra generally indicate the absence of the $v(\mathrm{NH})$ of compounds 3ab and also show the characteristic frequency of the new-formed functional group.

The mass spectra of all examined compounds showed the molecular ion. It is apparent that the mass spectra do not give reliable evidence to discriminate between the $S$ - and $N$ - substituted derivatives.

${ }^{1} \mathrm{H}-\mathrm{NMR}$ spectroscopy did provide substantiation for the structures proposed for the $N$ - and $S$ products, respectively. Thus, the ${ }^{1} \mathrm{H}-\mathrm{NMR}$ spectra displayed an interesting multiplet peak corresponding to $\mathrm{H}(17)$ at chemical shifts ranging from ca. 10.50-10.26 ppm in the case of both the $\mathrm{N}$-alkyl (5) or N-acyl (8) derivatives [6]. The high chemical shift is attributed to magnetic anisotropy interaction between $\mathrm{C}=\mathrm{S}(11) \ldots \mathrm{H}(17)$ as shown in Figure 1 . This peak was used as an indicator for the $N$-substituted derivatives; the corresponding peaks for $\mathrm{H}(17)$ in the case of the $S$ substituted derivatives occurs at chemical shifts ranging from ca. 8.66-8.41 ppm for all examined compounds 4a-l. The ${ }^{1} \mathrm{H}-\mathrm{NMR}$ and ${ }^{13} \mathrm{C}-\mathrm{NMR}$ chemical shifts for the $\mathrm{SCH}_{2}$ group of the S-alkylated derivatives $\mathbf{4 b}-\mathbf{l}$ are shown in Table 4. 
Table 4. ${ }^{1} \mathrm{H}$ NMR and ${ }^{13} \mathrm{C}$ NMR chemical shifts for the $\mathrm{SCH}_{2}$ group of the S-alkylated derivatives $\mathbf{4 b - 1}$

\begin{tabular}{|c|c|c|c|c|}
\hline $\begin{array}{c}\text { Compound } \\
\text { no. } \\
\end{array}$ & $\mathrm{SCH}_{2} \mathrm{R}$ & solvent & $\begin{array}{l}{ }^{1} \mathrm{H}-\mathrm{NMR} \text { chemical } \\
\text { shift }\left(\mathrm{SCH}_{2}\right) \mathrm{ppm}\end{array}$ & $\begin{array}{l}{ }^{13} \mathrm{C} \text {-NMR chemical } \\
\text { shift }\left(\mathrm{SCH}_{2}\right) \mathrm{ppm}\end{array}$ \\
\hline $4 b$ & $\mathrm{SCH}_{2} \mathrm{COOH}$ & $\mathrm{DMSO}_{-} \mathrm{d}_{6}$ & 4.18 & 36.69 \\
\hline $4 c$ & $\mathrm{SCH}_{2} \mathrm{COOCH}_{3}$ & $\mathrm{CDCl}_{3}$ & 4.23 & 35.92 \\
\hline 4d & $\mathrm{SCH}_{2} \mathrm{CONH}_{2}$ & $\mathrm{DMSO}_{-} \mathrm{d}_{6}$ & 4.04 & 37.50 \\
\hline $4 e$ & $\mathrm{SCH}_{2} \mathrm{COPh}$ & $\mathrm{CDCl}_{3}$ & 5.08 & 42.82 \\
\hline $4 f$ & $\mathrm{SCH}_{2} \mathrm{COPh}-\mathrm{p}-\mathrm{Cl}$ & $\mathrm{CDCl}_{3}$ & 5.02 & 42.33 \\
\hline $4 \mathrm{~g}$ & $\mathrm{SCH}_{2} \mathrm{COPh}-\mathrm{p}-\mathrm{OCH}_{3}$ & $\mathrm{CDCl}_{3}$ & 5.03 & 42.71 \\
\hline $4 h$ & $\mathrm{SCH}_{2} \mathrm{Ph}$ & $\mathrm{CDCl}_{3}$ & 4.63 & 38.94 \\
\hline $4 i$ & $\mathrm{SCH}_{2} \mathrm{CH}=\mathrm{CH}_{2}$ & $\mathrm{CDCl}_{3}$ & 4.15 & 36.79 \\
\hline $4 j$ & $\mathrm{SCH}_{2} \mathrm{CN}$ & $\mathrm{CDCl}_{3}$ & 4.24 & - \\
\hline $4 k$ & $\mathrm{SCH}_{2} \mathrm{CH}_{2} \mathrm{COOH}$ & DMSO- $_{6}$ & 3.42 & 33.59 \\
\hline
\end{tabular}

The ${ }^{1} \mathrm{H}-\mathrm{NMR}$ spectra of the $\mathrm{N}(2)$ substituted derivatives $\mathbf{5 a}$ and $\mathbf{5 b}$ gave peaks at chemical shifts of ca $4.59 \mathrm{ppm}$, corresponding to the $\mathrm{NCH}_{2}$ groups, while the ${ }^{13} \mathrm{C}-\mathrm{NMR}$ spectra show peaks at chemical shifts of ca 44.32 and $44.14 \mathrm{ppm}$, respectively. It is apparent from the reported data that the ${ }^{1} \mathrm{H}-\mathrm{NMR}$ and ${ }^{13} \mathrm{C}-\mathrm{NMR}$ chemical shifts of the $\mathrm{SCH}_{2}$ groupings occur at lower chemical shift than those of $\mathrm{NCH}_{2}$ taking into consideration the environment for the compared structures and the solvents used for the NMR experiments. Finally, the ${ }^{13} \mathrm{C}-\mathrm{NMR}$ spectra show peaks at chemical shifts of ca $163 \mathrm{ppm}$ due to the $\mathrm{C}=\mathrm{S}$ moiety which is associated with the $N$-acyl (8) and $N$-alkyl (5) derivatives, while $S$-alkylation gave peaks at a chemical shift of ca $144 \mathrm{ppm}$ for the same carbon $\mathrm{C}(1)$ (corresponding to $\mathrm{C}-\mathrm{S}$ ).

\section{Conclusions}

The regioselective alkylation and acylation reactions of thioamide derivative $\mathbf{3}$ with electrophiles can take place at either the sulfur or the nitrogen atoms depending on the electrophile used. Results of attack are determined by orbital/charge control and in the case of acylation agents by thermodynamic control of the reaction processes.

\section{Acknowledgments}

This work was supported by a grant from the Ministry of Education of the Czech Republic (Grant No. CEZ: J07/98: 143100011) and Grant Agency of the Czech Republic (Grant No. 203/01/1333). We would like to thank Analytical Department of PLIVA-Lachema Co., Brno, Czech Republic for elemental analysis. The authors thank the Czech Academic Supercomputer Center for providing the access to computer facilities. 


\section{Experimental}

\section{General}

Melting points of all the compounds were measured on a Boetius Rapido PHMK 79/2106 (Wägetechnik) instrument. TLC was carried out on Silufol UV 254 plates (Kavalier, Votice); the eluent used was a 1: 4 mixture of acetone and benzene. TLC detection was accomplished with a Fluotes Universal (Quarzlampen, Hanau) instrument and iodine vapours. The purity of compounds 2-8 was verified by their elemental analyses, measured with an 1102 (Erba) instrument. FTIR spectra were taken on a Genesis (Unicam) spectrometer using potassium bromide pellets. NMR spectra were measured on a Bruker Avance DRX-500 spectrometer. ${ }^{1} \mathrm{H}$ - and ${ }^{13} \mathrm{C}-\mathrm{NMR}$ spectra were measured in $\mathrm{CDCl}_{3},\left(\mathrm{CD}_{3}\right)_{2} \mathrm{SO}$ or $\mathrm{CF}_{3} \mathrm{COOD}$ solutions and tetramethylsilane was used as an internal standard. The measured ${ }^{13} \mathrm{C}$ - and ${ }^{1} \mathrm{H}$ - NMR spectra were correlated with those obtained by on-line simulation (Advanced Chemistry Development, Inc., Toronto, Canada). Mass spectra measured (electron impact, $70 \mathrm{eV}$ ) were with a FISONS INSTUMENTS TRIO 1000 and GC 8000 series apparatus.

The theoretical results were obtained using the DFT method at the B3LYP/6-31G** level [10,11]. Mulliken [12], ESP [13] and NBO [14-16] methods were used to calculate the partial charges and properties of molecular orbitals. Mayer bond orders [17] were calculated at a B3LYP/ii-iglo level using the demon v.l program [18].

The starting materials $\mathbf{1}, \mathbf{2}$ and $\mathbf{3}$ were prepared according to the method reported in literature $[8]$.

\section{2-Hydrazino-3-methyl-3,4-dihydro-4-quinazolinone (2).}

A mixture of quinazoline derivative $1(1.92 \mathrm{~g}, 0.01 \mathrm{~mol})$ and hydrazine hydrate $(2.5 \mathrm{ml}, 0.05$ $\mathrm{mol})$ in butanol $(40 \mathrm{ml})$ was stirred under reflux for $18 \mathrm{~h}$ until the evolution of hydrogen sulfide ceased. The reaction mixture was allowed to cool, and the resultant solid was filtered off. After dissolution of the product thus obtained in $3 \mathrm{M}$ hydrochloric acid solution, it was reprecipitated by the addition of aqueous ammonia solution to $\mathrm{pH} 8$, filtered, washed with water and crystallized from ethyl alcohol to give $1.42 \mathrm{~g}(65 \%)$ of the title compound as white crystals; M.p. $209-210^{\circ} \mathrm{C}$; Calculated for $\mathrm{C}_{9} \mathrm{H}_{10} \mathrm{~N}_{4} \mathrm{O}$ (190.21): $56.84 \% \mathrm{C}, 5.26 \% \mathrm{H}, 29.47 \% \mathrm{~N}$; Found: $56.25 \% \mathrm{C}, 5.01 \% \mathrm{H}$, $29.20 \% \mathrm{~N}$; FTIR, $\widetilde{v} / \mathrm{cm}^{-1}: 3300,3268\left(\mathrm{NH}_{2}\right), 1661$ (lactam $\left.\mathrm{C}=\mathrm{O}\right)$.

\section{4-Methyl-1-thioxo-1,2,4,5-tetrahydro[1,2,4]triazolo[4,3-a]quinazolin-5-one (3).}

To a suspension of hydrazine derivative $2(1.9 \mathrm{~g}, 0.01 \mathrm{~mol})$ in ethyl alcohol, a solution of potassium hydroxide $(1.12 \mathrm{~g}, 0.02 \mathrm{~mol})$ in water $(10 \mathrm{~mL})$ was added. After the addition of carbon disulfide $(7.6 \mathrm{~mL}, 0.1 \mathrm{~mol})$ the reaction mixture was refluxed gently on a water bath at $70{ }^{\circ} \mathrm{C}$ for $6 \mathrm{~h}$. Afterwards the solvent was evaporated under reduced pressure to complete dryness. The residue was redissolved in water and the solution thus obtained was acidified with $1 \mathrm{~N}$ hydrochloric 
acid solution to $\mathrm{pH}$ 1. The resultant flocculent precipitate was filtered, washed with water and crystallized from DMF to afford $1.74 \mathrm{~g}(75 \%)$ of the desired product as yellowish crystals M.p. 285-286 ${ }^{\circ} \mathrm{C}$; Calculated for $\mathrm{C}_{10} \mathrm{H}_{8} \mathrm{~N}_{4} \mathrm{OS}$ (232.27): $51.72 \% \mathrm{C}, 3.45 \% \mathrm{H}, 24.14 \% \mathrm{~N}, 13.80 \% \mathrm{~S}$, Found: $52.00 \% \mathrm{C}, 3.81 \% \mathrm{H}, 24.32 \% \mathrm{~N}, 13.65 \% \mathrm{~S}$; FTIR, $\widetilde{v} / \mathrm{cm}^{-1}: 3177(\mathrm{NH}), 1672(\mathrm{C}=\mathrm{O}$, cyclic amide). The ${ }^{1} \mathrm{H}-\mathrm{NMR}$ proves the presence of the tautomeric mixture of $\mathbf{3 a}$ and $\mathbf{3 b}$ in about a $1: 1$ ratio. 3a: ${ }^{1} \mathrm{H}-\mathrm{NMR}\left(\mathrm{DMSO}_{\mathrm{d}}\right.$ ) $\delta / \mathrm{ppm}$ : 8.22-8.20 (1H, m, ArH), 7.90-7.85 (1H, m, ArH), 7.62-7.57 $(1 \mathrm{H}, \mathrm{m}, \mathrm{ArH}), 7.40-7.37(1 \mathrm{H}, \mathrm{m}, \mathrm{ArH}), 3.65\left(3 \mathrm{H}, \mathrm{s}, \mathrm{NCH}_{3}\right)$; Second series of chemical shifts corresponding to $3 \mathbf{b}$ : 10.21-10.18 (1H, m, ArH), 7.97-7.94 (1H, m, ArH), 7.74-7.69 (1H, m, ArH), 7.34-7.30 (1H, m, ArH), $3.44\left(3 \mathrm{H}, \mathrm{s}, \mathrm{NCH}_{3}\right) .{ }^{1} \mathrm{H}-\mathrm{NMR}\left(\mathrm{CF}_{3} \mathrm{COOD}\right) \delta / \mathrm{ppm}: 10.44-10.41(1 \mathrm{H}, \mathrm{m}$, ArH), 8.87-8.85 (1H, m, ArH), 8.40-8.35 (1H, m, ArH), 8.15-8.10 (1H, m, ArH), 4.19 (3H, s, $\left.\mathrm{NCH}_{3}\right) .{ }^{13} \mathrm{C}-\mathrm{NMR}\left(\mathrm{CF}_{3} \mathrm{COOD}\right) \delta / \mathrm{ppm}: 164.12(\mathrm{C}=\mathrm{S}), 163.64$ (lactam $\left.\mathrm{C}=\mathrm{O}\right), 148.69\left(\mathrm{C}_{\mathrm{q}}\right)$, 138.17( $\left(\mathrm{CH}_{\mathrm{Ar}}\right), 137.00\left(\mathrm{C}_{\mathrm{q}}\right), 131.67\left(\mathrm{CH}_{\mathrm{Ar}}\right), 131.03\left(\mathrm{CH}_{\mathrm{Ar}}\right), 119.21\left(\mathrm{CH}_{\mathrm{Ar}}\right), 31.44\left(\mathrm{NCH}_{3}\right)$.

\section{General Procedure for S-Alkylation with Alkyl Halides}

To a mixture of the triazolo derivative $3(2.32 \mathrm{~g}, 0.01 \mathrm{~mol})$ and triethylamine $(2 \mathrm{~mL}, 0.02 \mathrm{~mol})$ in ethyl alcohol $(30 \mathrm{~mL})$ the appropriate alkyl halide $(0.01 \mathrm{~mol})$ was added. The reaction mixture was heated under reflux for 4-6 h, and then concentrated under reduced pressure. The solid obtained was filtered and then recrystallized from ethyl alcohol.

4-Methyl-1-(methylsulfanyl)-4,5-dihydro[1,2,4]triazolo[4,3-a]quinazolin-5-one (4a).

(Alkylating agent: methyl iodide): yield $1.55 \mathrm{~g}(63 \%)$; M.p. 234-235 ${ }^{\circ} \mathrm{C}$; Calculated for $\mathrm{C}_{11} \mathrm{H}_{10} \mathrm{~N}_{4} \mathrm{OS}$ (246.29): $53.65 \% \mathrm{C}, 4.09 \% \mathrm{H}, 22.75 \% \mathrm{~N}, 13.02 \% \mathrm{~S}$, Found: $53.54 \% \mathrm{C}, 3.98 \% \mathrm{H}$, $22.62 \% \mathrm{~N}, 12.77 \% \mathrm{~S}$; FTIR, $\widetilde{v} / \mathrm{cm}^{-1}: 1686(\mathrm{C}=\mathrm{O}), 3000,2922(\mathrm{CH}), 1613(\mathrm{C}=\mathrm{N}) ;{ }^{1} \mathrm{H}-\mathrm{NMR}$ $\left(\mathrm{CDCl}_{3}\right) \delta /$ ppm: 8.45-8.42 (1H, m, ArH), 8.35-8.32 (1H, m, ArH), 7.85-7.80 (1H, m, ArH), 7.59$7.53(1 \mathrm{H}, \mathrm{m}, \mathrm{ArH}), 3.80\left(3 \mathrm{H}, \mathrm{s}, \mathrm{NCH}_{3}\right), 2.90\left(3 \mathrm{H}, \mathrm{s}, \mathrm{SCH}_{3}\right) ;{ }^{13} \mathrm{C}-\mathrm{NMR}\left(\mathrm{CDCl}_{3}\right) \delta / \mathrm{ppm}: 158.74$ (lactam $\mathrm{C}=\mathrm{O}), 150.03\left(\mathrm{C}_{\mathrm{q}}\right), 145.81(\mathrm{C}-\mathrm{S}), 134.71\left(\mathrm{CH}_{\mathrm{Ar}}\right), 133.74\left(\mathrm{C}_{\mathrm{q}}\right), 130.24\left(\mathrm{CH}_{\mathrm{Ar}}\right), 126.97$ $\left(\mathrm{CH}_{\mathrm{Ar}}\right), 117.44\left(\mathrm{C}_{\mathrm{q}}\right), 115.99\left(\mathrm{CH}_{\mathrm{Ar}}\right), 29.78\left(\mathrm{NCH}_{3}\right), 16.27\left(\mathrm{SCH}_{3}\right)$.

2-[(4-Methyl-5-oxo-4,5-dihydro[1,2,4]triazolo[4,3-a]quinazolin-1-yl)sulfanyl]acetic acid (4b).

(Alkylating agent: chloroacetic acid); yield 1.89 g (65\%); M.p. 205-206 ${ }^{\circ} \mathrm{C}$; Calculated for $\mathrm{C}_{12} \mathrm{H}_{10} \mathrm{~N}_{4} \mathrm{O}_{3} \mathrm{~S}$ (290.30): 49.65\% C, 3.47\% H, 19.30\% N, 11.04\% S, Found: $49.42 \% \mathrm{C}, 3.45 \% \mathrm{H}$, 19.25\% N, 11.02\% S; FTIR, $\widetilde{v} / \mathrm{cm}^{-1}: 1675(\mathrm{C}=\mathrm{O}), 1711$ (acid $\mathrm{C}=\mathrm{O}$ ), 3304-2908 (broad, acid-OH), 2987, $2955(\mathrm{CH}), 1616(\mathrm{C}=\mathrm{N}) ;{ }^{1} \mathrm{H}-\mathrm{NMR}\left(\mathrm{DMSO}_{6}\right)$ / $/ \mathrm{ppm}$ : 8.41-8.39 (1H, m, ArH), 8.28-8.26 $(1 \mathrm{H}, \mathrm{m}, \mathrm{ArH}), 7.99-7.96(1 \mathrm{H}, \mathrm{m}, \mathrm{ArH}), 7.65-7.62(1 \mathrm{H}, \mathrm{m}, \mathrm{ArH}), 4.18\left(2 \mathrm{H}, \mathrm{s}, \mathrm{SCH}_{2} \mathrm{CO}\right), 3.58(3 \mathrm{H}$, s, $\left.\mathrm{NCH}_{3}\right) ;{ }^{13} \mathrm{C}-\mathrm{NMR}\left(\mathrm{DMSO}-\mathrm{d}_{6}\right) \delta /$ ppm: $169.86($ acid $\mathrm{C}=\mathrm{O}), 158.95($ lactam $\mathrm{C}=\mathrm{O}), 150.49\left(\mathrm{C}_{\mathrm{q}}\right)$, $143.59(\mathrm{C}-\mathrm{S}), 135.63\left(\mathrm{CH}_{\mathrm{Ar}}\right), 134.07\left(\mathrm{C}_{\mathrm{q}}\right), 129.89\left(\mathrm{CH}_{\mathrm{Ar}}\right), 127.65\left(\mathrm{CH}_{\mathrm{Ar}}\right), 117.92\left(\mathrm{C}_{\mathrm{q}}\right), 116.52$ $\left(\mathrm{CH}_{\mathrm{Ar}}\right), 36.69\left(\mathrm{SCH}_{2}\right), 29.95\left(\mathrm{NCH}_{3}\right)$. 
Methyl-2-[(4-methyl-5-oxo-4,5-dihydro[1,2,4]triazolo[4,3-a]quinazolin-1-yl)sulfanyl]acetate (4c).

(Alkylating agent: methyl chloroacetate): yield 1.37 g (45\%); M.p. 150-151 ${ }^{\circ} \mathrm{C}$; Calculated for $\mathrm{C}_{13} \mathrm{H}_{12} \mathrm{~N}_{4} \mathrm{O}_{3} \mathrm{~S}$ (304.32): $51.31 \% \mathrm{C}, 3.97 \% \mathrm{H}, 18.41 \% \mathrm{~N}, 10.53 \% \mathrm{~S}$, Found: $51.28 \% \mathrm{C}, 3.83 \% \mathrm{H}$, $18.23 \% \mathrm{~N}, 10.51 \% \mathrm{~S} ; \widetilde{v} / \mathrm{cm}^{-1}: 1675(\mathrm{C}=\mathrm{O}), 1741($ ester $\mathrm{C}=\mathrm{O}), 2987,2955(\mathrm{CH}), 1616(\mathrm{C}=\mathrm{N}) ;{ }^{1} \mathrm{H}-$ NMR $\left(\mathrm{CDCl}_{3}\right) \delta /$ ppm: 8.45-8.41 (1H, m, ArH), 8.40-8.37 (1H, m, ArH), 7.85-7.80 (1H, m, ArH), 7.59-7.54 (1H, m, ArH), $4.23\left(2 \mathrm{H}, \mathrm{s}, \mathrm{SCH}_{2} \mathrm{CO}\right), 3.78\left(3 \mathrm{H}, \mathrm{s}, \mathrm{OCH}_{3}\right), 3.76\left(3 \mathrm{H}, \mathrm{s}, \mathrm{NCH}_{3}\right)$; ${ }^{13} \mathrm{C}-\mathrm{NMR}$ $\left(\mathrm{CDCl}_{3}\right)$ \&/ ppm: 168.51 (ester $\left.\mathrm{C}=\mathrm{O}\right), 158.71$ (lactam $\left.\mathrm{C}=\mathrm{O}\right), 150.17\left(\mathrm{C}_{\mathrm{q}}\right), 143.39(\mathrm{C}-\mathrm{S}), 134.87$ $\left(\mathrm{CH}_{\mathrm{Ar}}\right), 133.59\left(\mathrm{C}_{\mathrm{q}}\right), 130.51\left(\mathrm{CH}_{\mathrm{Ar}}\right), 127.45\left(\mathrm{CH}_{\mathrm{Ar}}\right), 117.52\left(\mathrm{C}_{\mathrm{q}}\right), 116.54\left(\mathrm{CH}_{\mathrm{Ar}}\right), 53.24\left(\mathrm{OCH}_{2}\right)$, $35.92\left(\mathrm{SCH}_{2}\right), 29.88\left(\mathrm{NCH}_{3}\right)$; Mass spectrum, m/z (I/ $\left./ \%\right): 304$ (46), 273 (9), 246 (14), 245 (100), 244 (36), 231 (8), 203 (10), 162 (57), 159(11), 134 (24), 104 (4), 102 (7), 90 (28), 76 (7).

\section{2-[(4-Methyl-5-oxo-4,5-dihydro[1,2,4]triazolo[4,3-a]quinazolin-1-yl) sulfanyl]acetamide (4d)}

(Alkylating agent: chloroacetamide): yield $2.02 \mathrm{~g}$ (70\%); M.p. 225-226 ${ }^{\circ} \mathrm{C}$; Calculated for $\mathrm{C}_{12} \mathrm{H}_{11} \mathrm{~N}_{5} \mathrm{O}_{2} \mathrm{~S}$ (289.31): 49.82\% C, 3.83\% H, 24.21\% N, 11.08\% S, Found: $49.77 \% \mathrm{C}, 3.62 \% \mathrm{H}$, $24.06 \% \mathrm{~N}, 10.83 \% \mathrm{~S} ; \widetilde{v} / \mathrm{cm}^{-1}: 1690(\mathrm{C}=\mathrm{O}), 1690$ (amide $\left.\mathrm{C}=\mathrm{O}\right), 3355,3173\left(\mathrm{NH}_{2}\right), 3011,2966$, $2924(\mathrm{CH}), 1610(\mathrm{C}=\mathrm{N}) ;{ }^{1} \mathrm{H}-\mathrm{NMR}\left(\mathrm{DMSO}_{\mathrm{d}}\right)$ ) $/ \mathrm{ppm}$ : 8.48-8.45 (1H, m, ArH), 8.26-8.23 (1H, m, ArH), 7.99-7.93 (1H, m, ArH), $7.68\left(1 \mathrm{H}, \mathrm{bs}, \mathrm{NH}_{2}\right), 7.64-7.59$ (1H, m, ArH), 7.25 (1H, bs, NH2), $4.04\left(2 \mathrm{H}, \mathrm{s}, \mathrm{SCH}_{2} \mathrm{CO}\right), 3.58\left(3 \mathrm{H}, \mathrm{s}, \mathrm{NCH}_{3}\right) ;{ }^{13} \mathrm{C}-\mathrm{NMR}\left(\mathrm{DMSO}-\mathrm{d}_{6}\right) \delta / \mathrm{ppm}$ : 168.31 (amide $\left.\mathrm{C}=\mathrm{O}\right)$, 158.16 (lactam $\mathrm{C}=\mathrm{O}), 149.57\left(\mathrm{C}_{\mathrm{q}}\right), 143.07(\mathrm{C}-\mathrm{S}), 134.79\left(\mathrm{CH}_{\mathrm{Ar}}\right), 133.32\left(\mathrm{C}_{\mathrm{q}}\right), 128.97\left(\mathrm{CH}_{\mathrm{Ar}}\right)$, $126.79\left(\mathrm{CH}_{\mathrm{Ar}}\right), 117.01\left(\mathrm{C}_{\mathrm{q}}\right), 115.76\left(\mathrm{CH}_{\mathrm{Ar}}\right), 37.50\left(\mathrm{SCH}_{2}\right), 29.12\left(\mathrm{NCH}_{3}\right)$.

\section{4-Methyl-1-[(2-oxo-2-phenylethyl)sulfanyl]-4,5-dihydro[1,2,4]triazolo[4,3-a]quinazolin-5-one} (4e).

(Alkylating agent: phenacyl bromide): yield 2.31 g (66\%); M.p. 218-219 ${ }^{\circ} \mathrm{C}$; Calculated for $\mathrm{C}_{18} \mathrm{H}_{14} \mathrm{~N}_{4} \mathrm{O}_{2} \mathrm{~S}$ (350.39): $61.70 \% \mathrm{C}, 4.03 \% \mathrm{H}, 15.99 \% \mathrm{~N}, 9.15 \% \mathrm{~S}$, Found: $61.52 \% \mathrm{C}, 3.89 \% \mathrm{H}$, $15.73 \% \mathrm{~N}, 9.08 \% \mathrm{~S} ; \widetilde{v} / \mathrm{cm}^{-1}: 1682(\mathrm{C}=\mathrm{O}), 1695(\mathrm{C}=\mathrm{O}), 3039,2974,2917(\mathrm{CH}), 1611(\mathrm{C}=\mathrm{N}) ;{ }^{1} \mathrm{H}-$ NMR $\left(\mathrm{CDCl}_{3}\right) \delta /$ ppm: 8.46-8.45 (1H, m, ArH), 8.43-8.42 (1H, m, ArH), 8.04-8.03 (2H, m, ArH), 7.85-7.82 (1H, m, ArH), 7.64-7.61 (1H, m, ArH), 7.58-7.55 (1H, m, ArH), 7.51-7.48 (2H, m, ArH), $5.08\left(2 \mathrm{H}, \mathrm{s}, \mathrm{SCH}_{2} \mathrm{CO}\right), 3.77\left(3 \mathrm{H}, \mathrm{s}, \mathrm{NCH}_{3}\right) ;{ }^{13} \mathrm{C}-\mathrm{NMR}\left(\mathrm{CDCl}_{3}\right) \delta / \mathrm{ppm}: 192.94(\mathrm{C}=\mathrm{O}), 158.73$ $(\operatorname{lactam} \mathrm{C}=\mathrm{O}), 150.05\left(\mathrm{C}_{\mathrm{q}}\right), 144.25(\mathrm{C}-\mathrm{S}), 135.35\left(\mathrm{C}_{\mathrm{q}}\right), 134.87\left(\mathrm{CH}_{\mathrm{Ar}}\right), 134.32\left(\mathrm{CH}_{\mathrm{Ar}}\right), 133.60\left(\mathrm{C}_{\mathrm{q}}\right)$, $130.26\left(\mathrm{CH}_{\mathrm{Ar}}\right), 129.11\left(\mathrm{CH}_{\mathrm{Ar}}\right), 128.78\left(\mathrm{CH}_{\mathrm{Ar}}\right), 127.22\left(\mathrm{CH}_{\mathrm{Ar}}\right), 117.45\left(\mathrm{C}_{\mathrm{q}}\right), 116.32\left(\mathrm{CH}_{\mathrm{Ar}}\right), 42.82$ $\left(\mathrm{SCH}_{2}\right), 29.79\left(\mathrm{NCH}_{3}\right)$.

\section{1-\{[(2-(4-Chlorophenyl)-2-oxoethyl] sulfanyl\}-4-methyl-4,5-dihydro[1,2,4]triazolo[4,3-a]- quinazolin-5-one (4f).}

(Alkylating agent: 4-chlorophenacyl bromide): yield: 2.76 g (72\%), M.p. 216-217 ${ }^{\circ} \mathrm{C}$; Calculated for $\mathrm{C}_{18} \mathrm{H}_{13} \mathrm{ClN}_{4} \mathrm{O}_{2} \mathrm{~S}$ (384.84): $56.18 \% \mathrm{C}, 3.40 \% \mathrm{H}, 9.21 \% \mathrm{Cl}, 14.56 \% \mathrm{~N}, 8.33 \% \mathrm{~S}$, Found: $56.16 \%$ 
C, 3.37\% H, 9.11\% Cl, 14.49\% N, 8.33\% S; $\widetilde{v} / \mathrm{cm}^{-1}: 1680(\mathrm{C}=\mathrm{O}), 1694(\mathrm{C}=\mathrm{O}), 2970,2907(\mathrm{CH})$, $1615(\mathrm{C}=\mathrm{N})$; ${ }^{1} \mathrm{H}-\mathrm{NMR}\left(\mathrm{CDCl}_{3}\right) \delta / \mathrm{ppm}: 8.45-8.44(1 \mathrm{H}, \mathrm{m}, \mathrm{ArH}), 8.43-8.41(1 \mathrm{H}, \mathrm{m}, \mathrm{ArH}), 8.00-$ 7.97 (2H, m, ArH), 7.86-7.81 (1H, m, ArH), 7.60-7.55 (1H, m, ArH), 7.49-7.46 (2H, m, ArH), 5.02 $\left(2 \mathrm{H}, \mathrm{s}, \mathrm{SCH}_{2} \mathrm{CO}\right), 3.77\left(3 \mathrm{H}, \mathrm{s}, \mathrm{NCH}_{3}\right) ;{ }^{13} \mathrm{C}-\mathrm{NMR}\left(\mathrm{CDCl}_{3}\right) \delta / \mathrm{ppm}: 191.86(\mathrm{C}=\mathrm{O}), 158.73$ (lactam $\mathrm{C}=\mathrm{O}), 150.05\left(\mathrm{C}_{\mathrm{q}}\right), 144.25(\mathrm{C}-\mathrm{S}), 140.99\left(\mathrm{CH}_{\mathrm{Ar}}\right), 134.91\left(\mathrm{C}_{\mathrm{q}}\right), 134.87\left(\mathrm{CH}_{\mathrm{Ar}}\right), 133.77\left(\mathrm{C}_{\mathrm{q}}\right), 130.37$ $\left(\mathrm{CH}_{\mathrm{Ar}}\right), 130.20\left(\mathrm{CH}_{\mathrm{Ar}}\right), 129.50\left(\mathrm{CH}_{\mathrm{Ar}}\right), 127.31\left(\mathrm{CH}_{\mathrm{Ar}}\right), 117.53\left(\mathrm{C}_{\mathrm{q}}\right), 116.29\left(\mathrm{CH}_{\mathrm{Ar}}\right), 42.33\left(\mathrm{SCH}_{2}\right)$, $29.83\left(\mathrm{NCH}_{3}\right)$.

\section{1-\{[(2-(4-Methoxyphenyl)-2-oxoethyl] sulfanyl\}-4-Methyl4,5-dihydro[1,2,4]triazolo[4,3-a]-} quinazolin-5-one (4g).

(Alkylating agent: 4-methoxyphenacyl bromide): yield 2.47 g (65\%); M.p. 194-195 ${ }^{\circ} \mathrm{C}$; Calculated for $\mathrm{C}_{19} \mathrm{H}_{16} \mathrm{~N}_{4} \mathrm{O}_{3} \mathrm{~S}$ (380.42): $59.99 \% \mathrm{C}, 4.24 \% \mathrm{H}, 14.73 \% \mathrm{~N}, 8.43 \% \mathrm{~S}$, Found: $59.64 \% \mathrm{C}, 4.21 \% \mathrm{H}$, $14.67 \% \mathrm{~N}, 8.36 \% \mathrm{~S} ; \widetilde{v} / \mathrm{cm}^{-1}: 1670(\mathrm{C}=\mathrm{O}), 1688(\mathrm{C}=\mathrm{O}), 3009,2959(\mathrm{CH}), 1614(\mathrm{C}=\mathrm{N}) ;{ }^{1} \mathrm{H}-\mathrm{NMR}$

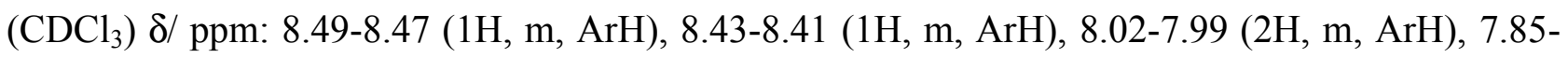
$7.80(1 \mathrm{H}, \mathrm{m}, \mathrm{ArH}), 7.58-7.54(1 \mathrm{H}, \mathrm{m}, \mathrm{ArH}), 6.69-6.93(2 \mathrm{H}, \mathrm{m}, \mathrm{ArH}), 5.03\left(2 \mathrm{H}, \mathrm{s}, \mathrm{SCH}_{2} \mathrm{CO}\right), 3.88$ $\left(3 \mathrm{H}, \mathrm{s}, \mathrm{OCH}_{3}\right), 3.77\left(3 \mathrm{H}, \mathrm{s}, \mathrm{NCH}_{3}\right) ;{ }^{13} \mathrm{C}-\mathrm{NMR}\left(\mathrm{CDCl}_{3}\right) \delta / \mathrm{ppm}: 191.43(\mathrm{C}=\mathrm{O}), 158.78$ (lactam $\mathrm{C}=\mathrm{O}), 151.67\left(\mathrm{C}_{\mathrm{q}}\right), 144.25(\mathrm{C}-\mathrm{S}), 134.91\left(\mathrm{C}_{\mathrm{q}}\right), 134.89\left(\mathrm{CH}_{\mathrm{Ar}}\right), 133.67\left(\mathrm{C}_{\mathrm{q}}\right), 131.21\left(\mathrm{CH}_{\mathrm{Ar}}\right), 130.23$ $\left(\mathrm{CH}_{\mathrm{Ar}}\right), 128.38\left(\mathrm{C}_{\mathrm{q}}\right), 127.22\left(\mathrm{CH}_{\mathrm{Ar}}\right), 117.48\left(\mathrm{C}_{\mathrm{q}}\right), 116.42\left(\mathrm{CH}_{\mathrm{Ar}}\right), 114.31\left(\mathrm{CH}_{\mathrm{Ar}}\right), 55.79\left(\mathrm{OCH}_{3}\right)$, $42.71\left(\mathrm{SCH}_{2}\right), 29.80\left(\mathrm{NCH}_{3}\right)$.

1-(Benzylsulfanyl)-4-methyl-4,5-dihydro[1,2,4]triazolo[4,3-a]quinazolin-5-one (4h).

(Alkylating agent: benzyl bromide): yield $2.13 \mathrm{~g}$ (66\%); M.p. 151-152 ${ }^{\circ} \mathrm{C}$; Calculated for $\mathrm{C}_{17} \mathrm{H}_{14} \mathrm{~N}_{4} \mathrm{OS}$ (322.38): 63.34\% C, 4.38\% H, 17.38\% N, 9.94\% S, Found: $63.25 \% \mathrm{C}, 4.36 \% \mathrm{H}$, $17.19 \% \mathrm{~N}, 9.81 \% \mathrm{~S} ; \widetilde{v} / \mathrm{cm}^{-1}: 1679(\mathrm{C}=\mathrm{O}), 3034,2937(\mathrm{CH}), 1603(\mathrm{C}=\mathrm{N}) ;{ }^{1} \mathrm{H}-\mathrm{NMR}\left(\mathrm{CDCl}_{3}\right) \delta /$ ppm: 8.43-8.39 (1H, m, ArH), 8.37-8.36 (1H, m, ArH), 7.77-7.71 (1H, m, ArH), 7.54-7.48 (1H, m, $\mathrm{ArH}), 7.44-7.42(2 \mathrm{H}, \mathrm{m}, \mathrm{ArH}), 7.32-7.25(3 \mathrm{H}, \mathrm{m}, \mathrm{ArH}), 4.63\left(2 \mathrm{H}, \mathrm{s}, \mathrm{SCH}_{2} \mathrm{Ph}\right), 3.78\left(3 \mathrm{H}, \mathrm{s}, \mathrm{NCH}_{3}\right)$;

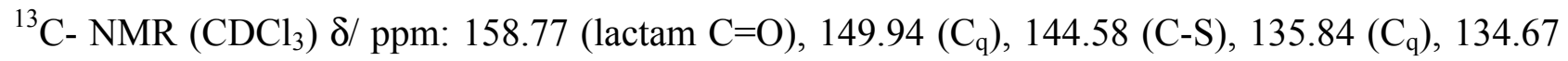
$\left(\mathrm{CH}_{\mathrm{Ar}}\right), 133.75\left(\mathrm{C}_{\mathrm{q}}\right), 130.20\left(\mathrm{CH}_{\mathrm{Ar}}\right), 129.53\left(\mathrm{CH}_{\mathrm{Ar}}\right), 128.95\left(\mathrm{CH}_{\mathrm{Ar}}\right), 128.26\left(\mathrm{CH}_{\mathrm{Ar}}\right), 127.04\left(\mathrm{CH}_{\mathrm{Ar}}\right)$, $117.45\left(\mathrm{C}_{\mathrm{q}}\right), 116.26\left(\mathrm{CH}_{\mathrm{Ar}}\right), 38.94\left(\mathrm{SCH}_{2}\right), 29.80\left(\mathrm{NCH}_{3}\right)$.

\section{1-(Allylsulfanyl)-4-methyl-4,5-dihydro[1,2,4]triazolo[4,3-a]quinazolin-5-one (4i).}

(Alkylating agent: allyl bromide): yield $1.50 \mathrm{~g}$ (55\%); M.p. 110-111 ${ }^{\circ} \mathrm{C}$; Calculated for $\mathrm{C}_{13} \mathrm{H}_{12} \mathrm{~N}_{4} \mathrm{OS}$ (272.32): 57.34\% C, 4.44\% H, 20.57\% N, 11.77\% S, Found: $57.18 \% \mathrm{C}, 4.38 \% \mathrm{H}$, $20.48 \% \mathrm{~N}, 11.53 \% \mathrm{~S} ; \widetilde{v} / \mathrm{cm}^{-1}: 1681(\mathrm{C}=\mathrm{O}), 2987,2955(\mathrm{CH}), 1630(\mathrm{C}=\mathrm{N}) ;{ }^{1} \mathrm{H}-\mathrm{NMR}\left(\mathrm{CDCl}_{3}\right) \delta /$ ppm: 8.53-8.49 (1H, m, ArH), 8.31-8.27 (1H, m, ArH), 7.82-7.78 (1H, m, ArH), 7.64-7.62 (1H, m, $\mathrm{ArH}), 6.02-6.12\left(1 \mathrm{H}, \mathrm{m}, \mathrm{CH}=\mathrm{CH}_{2}\right), 5.22\left(1 \mathrm{H}, \mathrm{d}, \mathrm{CH}=\mathrm{CH}_{2}, \mathrm{~J}=9.52 \mathrm{~Hz}\right), 5.09\left(1 \mathrm{H}, \mathrm{d}, \mathrm{CH}=\mathrm{CH}_{2}, \mathrm{~J}=\right.$ $8.4 \mathrm{~Hz}), 4.15\left(2 \mathrm{H}, \mathrm{d}, \mathrm{SCH}_{2}, \mathrm{~J}=5.45 \mathrm{~Hz}\right) 3.80\left(3 \mathrm{H}, \mathrm{s}, \mathrm{NCH}_{3}\right) ;{ }^{13} \mathrm{C}-\mathrm{NMR}\left(\mathrm{CDCl}_{3}\right) \delta / \mathrm{ppm}: 158.58$ $\left(\mathrm{C}=\mathrm{O}\right.$, cyclic amide), $149.72\left(\mathrm{C}_{\mathrm{q}}\right), 144.04(\mathrm{C}-\mathrm{S}), 134.52\left(\mathrm{CH}_{\mathrm{Ar}}\right), 133.61\left(\mathrm{C}_{\mathrm{q}}\right), 131.86\left(\mathrm{CH}=\mathrm{CH}_{2}\right)$, 
$130.01\left(\mathrm{CH}_{\mathrm{Ar}}\right), 129.89\left(\mathrm{CH}_{\mathrm{Ar}}\right), 126.89\left(\mathrm{CH}_{\mathrm{Ar}}\right), 119.89\left(\mathrm{CH}=\mathrm{CH}_{2}\right), 117.27\left(\mathrm{C}_{\mathrm{q}}\right), 116.00\left(\mathrm{CH}_{\mathrm{Ar}}\right)$, $36.79\left(\mathrm{SCH}_{2}\right), 29.56\left(\mathrm{NCH}_{3}\right)$; Mass spectrum, m/z (I $\left./ \mathrm{r} / \%\right): 272$ (29), 257 (100), 239 (12), 231 (3), 203 (6), 162 (31), 159 (10), 143 (5), 134(14), 90 (19), 76 (5).

\section{2-[(4-Methyl-5-oxo-4,5-dihydro[1,2,4]triazolo[4,3-a]quinazolin-1-yl)sulfanyl]acetonitrile (4j).}

(Alkylating agent: chloroacetonitrile): yield 1.60 g (59\%), M.p. 236-237 ${ }^{\circ} \mathrm{C}$; Calculated for $\mathrm{C}_{12} \mathrm{H}_{9} \mathrm{~N}_{5} \mathrm{OS}$ (271.30): 53.13\% C, 3.34\% H, 25.81\% N, 11.82\% S, Found: $53.11 \% \mathrm{C}, 3.34 \% \mathrm{H}$, $25.79 \% \mathrm{~N}, 11.82 \% \mathrm{~S} ; \widetilde{v} / \mathrm{cm}^{-1}: 1685(\mathrm{C}=\mathrm{O}), 2248(\mathrm{CN}), 3048,2980,2933(\mathrm{CH}), 1610(\mathrm{C}=\mathrm{N}) ;{ }^{1} \mathrm{H}-$ NMR $\left(\mathrm{CDCl}_{3}\right) \delta / \mathrm{ppm}$ : 8.50-8.48 (1H, m, ArH), 8.27-8.24 (1H, m, ArH), 7.90-7.85 (1H, m, ArH), 7.65-7.60 (1H, m, ArH), $4.24\left(2 \mathrm{H}, \mathrm{s}, \mathrm{SCH}_{2}\right), 3.81\left(3 \mathrm{H}, \mathrm{s}, \mathrm{NCH}_{3}\right) ;{ }^{1} \mathrm{H} \mathrm{NMR}\left(\mathrm{CF}_{3} \mathrm{COOD}\right) \delta / \mathrm{ppm}$ : 8.80-8.77 (1H, m, ArH), 8.54-8.51 (1H, m, ArH), 8.34-8.29 (1H, m, ArH), 8.11-8.06 (1H, m, ArH), $4.62\left(2 \mathrm{H}, \mathrm{s}, \mathrm{SCH}_{2}\right), 4.12\left(3 \mathrm{H}, \mathrm{s}, \mathrm{NCH}_{3}\right) ;{ }^{13} \mathrm{C}-\mathrm{NMR}\left(\mathrm{CF}_{3} \mathrm{COOD}\right) \mathrm{\delta} / \mathrm{ppm}$ : 158.97 (lactam $\left.\mathrm{C}=\mathrm{O}\right)$, $149.78\left(\mathrm{C}_{\mathrm{q}}\right), 148.15(\mathrm{C}-\mathrm{S}), 139.60\left(\mathrm{CH}_{\mathrm{Ar}}\right), 134.26\left(\mathrm{C}_{\mathrm{q}}\right), 133.20\left(\mathrm{CH}_{\mathrm{Ar}}\right), 132.92\left(\mathrm{CH}_{\mathrm{Ar}}\right), 115.58$ $(\mathrm{CN}), 32.47\left(\mathrm{NCH}_{3}\right), 20.61\left(\mathrm{SCH}_{2}\right)$.

3-[(4-Methyl-5-oxo-4,5-dihydro[1,2,4]triazolo[4,3-a]quinazolin-1-yl)sulfanyl]propionic acid (4k).

(Alkylating agent: chloropropionic acid): yield 1.58 g (52\%), M.p. 216-217 ${ }^{\circ} \mathrm{C}$; Calculated for $\mathrm{C}_{13} \mathrm{H}_{12} \mathrm{~N}_{4} \mathrm{O}_{3} \mathrm{~S}$ (304.32): $51.31 \% \mathrm{C}, 3.97 \% \mathrm{H}, 18.41 \% \mathrm{~N}, 10.53 \% \mathrm{~S}$, Found: $51.19 \% \mathrm{C}, 3.83 \% \mathrm{H}$, $18.14 \% \mathrm{~N}, 10.49 \% \mathrm{~S}$; FTIR, $\widetilde{v} / \mathrm{cm}^{-1}: 1687(\mathrm{C}=\mathrm{O}), 1711$ (C=O acid), 3304-2908 (OH-acid broad), 2987, $2955(\mathrm{CH}), 1613(\mathrm{C}=\mathrm{N}) ;{ }^{1} \mathrm{H}-\mathrm{NMR}\left(\mathrm{DMSO}_{6}\right)$ d/ ppm: 8.48-8.45 (1H, m, ArH), 8.25-8.22 $(1 \mathrm{H}, \mathrm{m}, \mathrm{ArH}), 7.96-7.91(1 \mathrm{H}, \mathrm{m}, \mathrm{ArH}), 7.63-7.58(1 \mathrm{H}, \mathrm{m}, \mathrm{ArH}), 3.58\left(3 \mathrm{H}, \mathrm{s}, \mathrm{NCH}_{3}\right), 3.42(2 \mathrm{H}, \mathrm{t}$, $\left.\mathrm{SCH}_{2}, \mathrm{~J}=6.72 \mathrm{~Hz}\right), 2.77\left(2 \mathrm{H}, \mathrm{t}, \mathrm{CH}_{2} \mathrm{CO}, \mathrm{J}=6.72 \mathrm{~Hz}\right) ;{ }^{13} \mathrm{C}-\mathrm{NMR}\left(\mathrm{DMSO}_{6} \mathrm{~d}_{6}\right) \delta / \mathrm{ppm}$ : 172.51 (acid $\mathrm{C}=\mathrm{O}), 158.13(\operatorname{lactam} \mathrm{C}=\mathrm{O}), 149.68\left(\mathrm{C}_{\mathrm{q}}\right), 142.69(\mathrm{C}-\mathrm{S}), 134.69\left(\mathrm{CH}_{\mathrm{Ar}}\right), 133.39\left(\mathrm{C}_{\mathrm{q}}\right), 128.91$ $\left(\mathrm{CH}_{\mathrm{Ar}}\right), 126.68\left(\mathrm{CH}_{\mathrm{Ar}}\right), 117.08\left(\mathrm{C}_{\mathrm{q}}\right), 115.61\left(\mathrm{CH}_{\mathrm{Ar}}\right), 33.59\left(\mathrm{SCH}_{2}\right), 29.05\left(\mathrm{NCH}_{3}\right), 28.85\left(\mathrm{CH}_{2} \mathrm{CO}\right)$.

\section{1-(Isopropylsulfanyl)-4-methyl-4,5-dihydro[1,2,4]triazolo[4,3-a]quinazolin-5-one (4I).}

(Alkylating agent: isopropyl iodide) yield $1.09 \mathrm{~g}$ (40\%), M.p. $148-149{ }^{\circ} \mathrm{C}$; Calculated for $\mathrm{C}_{13} \mathrm{H}_{14} \mathrm{~N}_{4} \mathrm{OS}$ (274.34): $56.92 \% \mathrm{C}, 5.14 \% \mathrm{H}, 20.42 \% \mathrm{~N}, 11.69 \% \mathrm{~S}$, Found: $56.77 \% \mathrm{C}, 5.10 \% \mathrm{H}$, $20.35 \% \mathrm{~N}, 11.57 \% \mathrm{~S}$; FTIR, $\widetilde{v} / \mathrm{cm}^{-1}: 1684(\mathrm{C}=\mathrm{O}), 2987,2961(\mathrm{CH}), 1614(\mathrm{C}=\mathrm{N})$; ${ }^{1} \mathrm{H}-\mathrm{NMR}$ $\left(\mathrm{CDCl}_{3}\right)$ \&/ ppm: 8.66-8.63 (1H, m, ArH), 8.44-8.41 (1H, m, ArH), 7.83-7.78 (1H, m, ArH), 7.57$7.52(1 \mathrm{H}, \mathrm{m}, \mathrm{ArH}), 4.13-3.99(1 \mathrm{H}, \mathrm{m}, \mathrm{SCH}), 3.80\left(3 \mathrm{H}, \mathrm{s}, \mathrm{NCH}_{3}\right), 1.51\left(6 \mathrm{H}, \mathrm{d}, \mathrm{CH}\left(\mathrm{CH}_{3}\right)_{2}, \mathrm{~J}=6.72\right.$

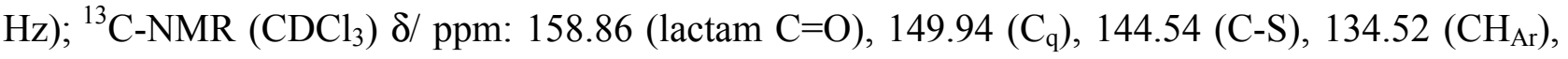
$134.11\left(\mathrm{C}_{\mathrm{q}}\right), 130.01\left(\mathrm{CH}_{\mathrm{Ar}}\right), 129.89\left(\mathrm{CH}_{\mathrm{Ar}}\right), 126.89\left(\mathrm{CH}_{\mathrm{Ar}}\right), 117.61\left(\mathrm{C}_{\mathrm{q}}\right), 116.00\left(\mathrm{CH}_{\mathrm{Ar}}\right), 40.80$ $(\mathrm{SCH}), 29.79\left(\mathrm{NCH}_{3}\right), 23.48\left(\mathrm{CH}\left(\mathrm{CH}_{3}\right)_{2}\right)$. 


\section{General Procedure for N-Alkylation with Alkyl Halides}

To a mixture of triazolo derivative $3(2.32 \mathrm{~g}, 0.01 \mathrm{~mol})$ and sodium hydroxide $(0.02 \mathrm{~mol})$ in absolute ethyl alcohol the appropriate alkyl halide $(0.01 \mathrm{~mol})$ was added. The reaction mixture was heated under reflux for $6 \mathrm{~h}$, concentrated under reduced pressure. The solid obtained was filtered, and crystallized from ethyl alcohol.

Ethyl-3-(4-methyl-5-oxo-1-thioxo-1,2,4,5-tetrahydro[1,2,4]triazolo[4,3-a]quinazolin-2-yl) propanoate (5a).

(Alkylating agent: ethyl-3-chloropropanoate): yield $1.43 \mathrm{~g}$ (45\%); M.p. 120-121 ${ }^{\circ} \mathrm{C}$; Calculated for $\mathrm{C}_{15} \mathrm{H}_{16} \mathrm{~N}_{4} \mathrm{O}_{3} \mathrm{~S}$ (332.38): 54.21\% C, 4.85\% H, 16.86\% N, 9.65\% S, Found: $54.15 \% \mathrm{C}, 4.76 \% \mathrm{H}$, $16.82 \%$ N, 9.57\% S; FTIR, $\widetilde{v} / \mathrm{cm}^{-1}: 1686(\mathrm{C}=\mathrm{O}), 1725(\mathrm{C}=\mathrm{O}$ ester $), 3087,2977(\mathrm{CH}), 1631(\mathrm{C}=\mathrm{N})$; ${ }^{1} \mathrm{H}-\mathrm{NMR}\left(\mathrm{CDCl}_{3}\right) \delta /$ ppm: 10.33-10.31 (1H, m, ArH), 8.36-8.34 (1H, m, ArH), 7.82-7.79 (1H, m, $\mathrm{ArH}), 7.58-7.56(1 \mathrm{H}, \mathrm{m}, \mathrm{ArH}), 4.59\left(1 \mathrm{H}, \mathrm{t}, \mathrm{NCH}_{2}, \mathrm{~J}=7.1 \mathrm{~Hz}\right), 4.18\left(1 \mathrm{H}, \mathrm{q}, \mathrm{OCH}_{2}, \mathrm{~J}=7.1 \mathrm{~Hz}\right), 3.61$ $\left(3 \mathrm{H}, \mathrm{s}, \mathrm{NCH}_{3}\right), 2.93\left(2 \mathrm{H}, \mathrm{t}, \mathrm{CH}_{2} \mathrm{CO}, \mathrm{J}=7.1 \mathrm{~Hz}\right), 1.29\left(3 \mathrm{H}, \mathrm{t}, \mathrm{CH}_{2} \underline{\mathrm{C}}_{3}, \mathrm{~J}=7.1 \mathrm{~Hz}\right) ;{ }^{13} \mathrm{C}-\mathrm{NMR}$ $\left(\mathrm{CDCl}_{3}\right)$ \&/ ppm: $170.51(\mathrm{C}=\mathrm{O}), 161.72(\mathrm{C}=\mathrm{S}), 158.36(\operatorname{lactam} \mathrm{C}=\mathrm{O}), 144.36\left(\mathrm{C}_{\mathrm{q}}\right), 135.13\left(\mathrm{C}_{\mathrm{q}}\right)$, $134.45\left(\mathrm{CH}_{\mathrm{Ar}}\right), 129.00\left(\mathrm{CH}_{\mathrm{Ar}}\right), 127.25\left(\mathrm{CH}_{\mathrm{Ar}}\right), 116.92\left(\mathrm{C}_{\mathrm{q}}\right), 116.55\left(\mathrm{CH}_{\mathrm{Ar}}\right), 60.96\left(\mathrm{OCH}_{2}\right), 44.32$ $\left(\mathrm{NCH}_{2}\right), 32.23\left(\mathrm{CH}_{2} \mathrm{CO}\right), 29.02\left(\mathrm{NCH}_{3}\right), 14.17\left(\mathrm{CH}_{2} \underline{\mathrm{CH}_{3}}\right)$.

\section{3-(4-Methyl-5-oxo-1-thioxo-1,2,4,5-tetrahydro[1,2,4]triazolo[4,3-a]quinazolin-2yl)propionitrile} (5b).

(Alkylating agent: 3-chloropropanenitrile): yield $1.20 \mathrm{~g} \mathrm{(40 \% ),} \mathrm{M.p.} \mathrm{230-231}{ }^{\circ} \mathrm{C}$; Calculated for $\mathrm{C}_{13} \mathrm{H}_{11} \mathrm{~N}_{5} \mathrm{OS}$ (285.32): $54.73 \% \mathrm{C}, 3.89 \% \mathrm{H}, 24.55 \% \mathrm{~N}, 11.24 \% \mathrm{~S}$, Found: $54.69 \% \mathrm{C}, 3.71 \% \mathrm{H}$, 24.45\% N, 11.12\% S; FTIR, $\widetilde{v} / \mathrm{cm}^{-1}: 1687(\mathrm{C}=\mathrm{O}), 2248(\mathrm{CN}), 3005,2978,2945(\mathrm{CH}), 1632$ $(\mathrm{C}=\mathrm{N}) ;{ }^{1} \mathrm{H}-\mathrm{NMR}\left(\mathrm{CDCl}_{3}\right) \delta / \mathrm{ppm}: 10.27-10.26(1 \mathrm{H}, \mathrm{m}, \mathrm{ArH}), 8.39-8.37(1 \mathrm{H}, \mathrm{m}, \mathrm{ArH}), 7.85-7.81$ $(1 \mathrm{H}, \mathrm{m}, \mathrm{ArH}), 7.60-7.56(1 \mathrm{H}, \mathrm{m}, \mathrm{ArH}), 4.59\left(2 \mathrm{H}, \mathrm{t}, \mathrm{NCH}_{2}, \mathrm{~J}=6.85 \mathrm{~Hz}\right), 3.64\left(3 \mathrm{H}, \mathrm{s}, \mathrm{NCH}_{3}\right), 3.03$ $\left(2 \mathrm{H}, \mathrm{t}, \mathrm{CH}_{2} \mathrm{CN}, \mathrm{J}=6.85 \mathrm{~Hz}\right) ;{ }^{13} \mathrm{C}-\mathrm{NMR}\left(\mathrm{CDCl}_{3}\right) \delta / \mathrm{ppm}: 162.20(\mathrm{C}=\mathrm{S}), 158.36$ (lactam $\left.\mathrm{C}=\mathrm{O}\right)$, $144.76\left(\mathrm{C}_{\mathrm{q}}\right), 135.13\left(\mathrm{C}_{\mathrm{q}}\right), 134.56\left(\mathrm{CH}_{\mathrm{Ar}}\right), 129.19\left(\mathrm{CH}_{\mathrm{Ar}}\right), 127.55\left(\mathrm{CH}_{\mathrm{Ar}}\right), 116.96\left(\mathrm{C}_{\mathrm{q}}\right), 116.32$ $\left(\mathrm{CH}_{\mathrm{Ar}}\right), 115.23(\mathrm{CN}), 44.14\left(\mathrm{NCH}_{2}\right), 29.10\left(\mathrm{NCH}_{3}\right), 16.09\left(\mathrm{CH}_{2} \mathrm{CN}\right)$; Mass spectrum, $\mathrm{m} / \mathrm{z}\left(\mathrm{I}_{\mathrm{r}} / \%\right)$ : 286 (18), 285 (100), 245 (34), 232 (29), 199 (3), 174 (5), 162 (12), 144 (8).

\section{Aryl substitution reaction}

\section{1-[(2,4-Dinitrophenyl)sulfanyl]-4-methyl-4,5-dihydro[1,2,4]triazolo[4,3-a]quinazolin-5-one (6).}

1-Chloro-2,4-dinitrobenzene $(0.01 \mathrm{~mol})$ was added to an alcoholic solution of triazolo derivative $3(2.32 \mathrm{~g}, 0.01 \mathrm{~mol})$ and triethylamine $(2 \mathrm{~mL}, 0.02 \mathrm{~mol})$ in ethyl alcohol. The reaction mixture was heated under reflux for $15 \mathrm{~min}$ to immediately give the product. The solid obtained was filtered, and crystallized from ethyl alcohol to give $3.26 \mathrm{~g}(82 \%)$ of the title compound; 
M.p. 319-320 ${ }^{\circ} \mathrm{C}$; Calculated for $\mathrm{C}_{16} \mathrm{H}_{10} \mathrm{~N}_{6} \mathrm{O}_{5} \mathrm{~S}$ (398.35): 48.24\% C, 2.53\% H, 21.10\% N, 8.05\% S, Found: $48.21 \% \mathrm{C}, 2.49 \% \mathrm{H}, 20.88 \% \mathrm{~N}, 7.91 \% \mathrm{~S}$; FTIR, $\widetilde{v} / \mathrm{cm}^{-1}: 1693(\mathrm{C}=\mathrm{O}), 3074,2955(\mathrm{CH})$, $1614(\mathrm{C}=\mathrm{N})$; ${ }^{1} \mathrm{H}-\mathrm{NMR}\left(\mathrm{CF}_{3} \mathrm{COOD}\right) \delta / \mathrm{ppm}: 9.56-9.54(1 \mathrm{H}, \mathrm{m}, \mathrm{ArH}), 9.09-9.06$ (1H, m, ArH), 8.918.89 (1H, m, ArH), 8.66-8.63 (1H, m, ArH), 8.27-8.22 (1H, m, ArH), 8.15-8.10 (1H, m, ArH), 7.70-7.67 (1H, m, ArH), $4.31\left(3 \mathrm{H}, \mathrm{s}, \mathrm{NCH}_{3}\right) ;{ }^{13} \mathrm{C}-\mathrm{NMR}\left(\mathrm{CF}_{3} \mathrm{COOD}\right) \mathrm{\delta} / \mathrm{ppm}: 162.20$ (lactam $\left.\mathrm{C}=\mathrm{O}\right)$, $152.12\left(\mathrm{C}_{\mathrm{q}}\right), 149.74\left(\mathrm{C}_{\mathrm{q}}\right), 148.16\left(\mathrm{C}_{\mathrm{q}}\right), 143.79(\mathrm{C}-\mathrm{S}), 139.67\left(\mathrm{C}_{\mathrm{q}}\right), 139.37\left(\mathrm{CH}_{\mathrm{Ar}}\right), 135.00\left(\mathrm{C}_{\mathrm{q}}\right)$, $133.12\left(\mathrm{CH}_{\mathrm{Ar}}\right), 132.86\left(\mathrm{CH}_{\mathrm{Ar}}\right), 132.31\left(\mathrm{CH}_{\mathrm{Ar}}\right), 131.22\left(\mathrm{CH}_{\mathrm{Ar}}\right), 124.46\left(\mathrm{CH}_{\mathrm{Ar}}\right), 119.60\left(\mathrm{C}_{\mathrm{q}}\right), 118.39$ $\left(\mathrm{CH}_{\mathrm{Ar}}\right), 32.52\left(\mathrm{NCH}_{3}\right)$.

\section{Acylation reactions: General procedure}

The appropriate acyl chloride (benzoyl chloride, pivaloyl chloride or ethyl chloroformate) (0.01 mol) was added to a mixture of triazolo derivative $3(2.32 \mathrm{~g}, 0.01 \mathrm{~mol})$ and triethylamine $(2 \mathrm{~mL}$, $0.02 \mathrm{~mol})$ solution in benzene $(30 \mathrm{~mL})$. The reaction mixture was heated under reflux for $15 \mathrm{~min}$. and then concentrated under reduced pressure. The solid obtained was filtered, and crystallized from ethyl alcohol. The obtained product was a mixture of both $\mathbf{7}$ and $\mathbf{8}$ and was not further purified. The purity of the isomers was determined from the corresponding ${ }^{1} \mathrm{H}-\mathrm{NMR}$ spectra. Compounds $\mathbf{7 a}$ and $\mathbf{7 b}$ were not isolated but detected only from the ${ }^{1} \mathrm{H}-\mathrm{NMR}$ spectra, FTIR spectroscopy and by the comparison with the ${ }^{1} \mathrm{H}-\mathrm{NMR}$ spectra of the pure $\mathbf{8 a}$ and $\mathbf{8 b}$. The mixture of compounds obtained from the above general procedure $7 \mathbf{a}, 8 \mathbf{a}$ or $7 \mathbf{b}, \mathbf{8 b}$ was heated under reflux in chloroform for $30 \mathrm{~min}$. to afford only the pure acyl derivatives $\mathbf{8 a}$ or $\mathbf{8 b}$.

Ethyl-[(4-methyl-5-oxo-4,5-dihydro[1,2,4]triazolo[4,3-a]quinazolin-1-yl)sulfanyl]methanoate (7a).

FTIR, $\widetilde{v} / \mathrm{cm}^{-1}: 1708(\mathrm{C}=\mathrm{O}), 1743(\mathrm{C}=\mathrm{O}$ ester $), 3063,2980(\mathrm{CH}), 1635(\mathrm{C}=\mathrm{N}) ;{ }^{1} \mathrm{H}-\mathrm{NMR}\left(\mathrm{CDCl}_{3}\right)$ 反/ ppm: 8.74-8.71 (1H, m, ArH), 8.45-8.42 (1H, m, ArH), 7.81-7.78 (1H, m, ArH), 7.56-7.53 (1H, m, ArH), $4.33\left(2 \mathrm{H}, \mathrm{q}, \mathrm{OCH}_{2}, \mathrm{~J}=7.0 \mathrm{~Hz}\right), 3,82\left(3 \mathrm{H}, \mathrm{s}, \mathrm{NCH}_{3}\right), 1,29\left(3 \mathrm{H}, \mathrm{t}, \mathrm{CH}_{2} \mathrm{CH}_{3}, \mathrm{~J}=7.0 \mathrm{~Hz}\right)$.

4-Methyl-5-oxo-4,5-dihydro[1,2,4]triazolo[4,3-a]quinazolin-1-yl-2,2-dimethylpropanethioate (7b).

FTIR, $\widetilde{v} / \mathrm{cm}^{-1}: 1691(\mathrm{C}=\mathrm{O}), 1743(\mathrm{C}=\mathrm{O}), 3002,2978(\mathrm{CH}), 1645(\mathrm{C}=\mathrm{N}) ;{ }^{1} \mathrm{H}-\mathrm{NMR}\left(\mathrm{CDCl}_{3}\right) \delta / \mathrm{ppm}$ : 8.62-8.59 (1H, m, ArH), 8.45-8.43 (1H, m, ArH), 7.83-7.79 (1H, m, ArH), 7.58-7.55 (1H, m, ArH), $3.84\left(3 \mathrm{H}, \mathrm{s}, \mathrm{NCH}_{3}\right), 1.61\left(9 \mathrm{H}, \mathrm{s}, \mathrm{C}\left(\mathrm{CH}_{3}\right)_{3}\right)$.

Ethyl-4-methyl-5-oxo-1-thioxo-1,2,4,5-tetrahydro[1,2,4]triazolo[4,3-a]quinazolin-2-carboxylate (8a).

Yield 1.64 g (54\%), M.p. 181-182 ${ }^{\circ} \mathrm{C}$; Calculated for $\mathrm{C}_{13} \mathrm{H}_{12} \mathrm{~N}_{4} \mathrm{O}_{3} \mathrm{~S}$ (304.32): 51.31\% C, 3.97\% H, $18.41 \% \mathrm{~N}, 10.53 \% \mathrm{~S}$, Found: $51.21 \% \mathrm{C}, 3.95 \% \mathrm{H}, 18.33 \% \mathrm{~N}, 10.42 \% \mathrm{~S} ; \mathrm{FTIR}, \widetilde{v} / \mathrm{cm}^{-1}: 1689$ $(\mathrm{C}=\mathrm{O}), 1778($ ester $\mathrm{C}=\mathrm{O}), 3063,2980(\mathrm{CH}), 1635(\mathrm{C}=\mathrm{N}) ;{ }^{1} \mathrm{H}-\mathrm{NMR}\left(\mathrm{CDCl}_{3}\right) \delta / \mathrm{ppm}:$ 10.41-10.38 (1H, m, ArH), 8.36-8.33 (1H, m, ArH), 7.81-7.78 (1H, m, ArH), 7.57-7.53 (1H, m, ArH), 4.55 (2H, 
q, $\left.\mathrm{OCH}_{2}, \mathrm{~J}=7.0 \mathrm{~Hz}\right), 3.66\left(3 \mathrm{H}, \mathrm{s}, \mathrm{NCH}_{3}\right), 1.50\left(3 \mathrm{H}, \mathrm{t}, \mathrm{CH}_{2} \mathrm{CH}_{3}, \mathrm{~J}=7.0 \mathrm{~Hz}\right) ;{ }^{13} \mathrm{C}-\mathrm{NMR}\left(\mathrm{CDCl}_{3}\right) \delta /$ ppm: $176.08(\mathrm{C}=\mathrm{O}), 164.75(\mathrm{C}=\mathrm{S}), 158.48(\operatorname{lactam} \mathrm{C}=\mathrm{O}), 149.04\left(\mathrm{C}_{\mathrm{q}}\right), 145.01\left(\mathrm{C}_{\mathrm{q}}\right), 135.18\left(\mathrm{C}_{\mathrm{q}}\right)$, $134.85\left(\mathrm{CH}_{\mathrm{Ar}}\right), 129.47\left(\mathrm{CH}_{\mathrm{Ar}}\right), 127.91\left(\mathrm{CH}_{\mathrm{Ar}}\right), 117.17\left(\mathrm{C}_{\mathrm{q}}\right), 116.55\left(\mathrm{CH}_{\mathrm{Ar}}\right), 65.30\left(\mathrm{OCH}_{2}\right), 29.36$ $\left(\mathrm{NCH}_{3}\right), 14.14 .36\left(\mathrm{CH}_{2} \mathrm{CH}_{3}\right)$.

2-(2,2-Dimethylpropanoyl)-4-methyl-1-thioxo-1,2,4,5-tetrahydro[1,2,4]triazolo[4,3-a]quinazolin5-one $(\mathbf{8 b})$.

Yield 1.42 g (45\%), M.p. 197-198 ${ }^{\circ} \mathrm{C}$; Calculated for $\mathrm{C}_{15} \mathrm{H}_{16} \mathrm{~N}_{4} \mathrm{O}_{2} \mathrm{~S}(316.38): 56.95 \% \mathrm{C}, 5.10 \% \mathrm{H}$, $17.71 \% \mathrm{~N}, 10.13 \% \mathrm{~S}$, Found: $56.73 \% \mathrm{C}, 4.97 \% \mathrm{H}, 17.65 \% \mathrm{~N}, 9.96 \% \mathrm{~S} ; \mathrm{FTIR}, \widetilde{v} / \mathrm{cm}^{-1}$ : 1691(C=O), $1743(\mathrm{C}=\mathrm{O}), 3002,2978(\mathrm{CH}), 1645(\mathrm{C}=\mathrm{N}) ;{ }^{1} \mathrm{H}-\mathrm{NMR}\left(\mathrm{CDCl}_{3}\right)$ d/ ppm: 10.50-10.47 $(1 \mathrm{H}, \mathrm{m}, \mathrm{ArH}), 8.40-8.37$ (1H, m, ArH), 7.84-7.79 (1H, m, ArH), 7.61-7.56 (1H, m, ArH), 3.67 $\left(3 \mathrm{H}, \mathrm{s}, \mathrm{NCH}_{3}\right), 1.52\left(9 \mathrm{H}, \mathrm{s}, \mathrm{C}\left(\mathrm{CH}_{3}\right)_{3}\right) ;{ }^{13} \mathrm{C}-\mathrm{NMR}\left(\mathrm{CDCl}_{3}\right) \delta / \mathrm{ppm}: 176.08(\mathrm{C}=\mathrm{O}), 164.71(\mathrm{C}=\mathrm{S})$, 158.65 (lactam $\mathrm{C}=\mathrm{O}), 143.89\left(\mathrm{C}_{\mathrm{q}}\right), 135.20\left(\mathrm{C}_{\mathrm{q}}\right), 134.79\left(\mathrm{CH}_{\mathrm{Ar}}\right), 129.50\left(\mathrm{CH}_{\mathrm{Ar}}\right), 127.88\left(\mathrm{CH}_{\mathrm{Ar}}\right)$, $117.09\left(\mathrm{C}_{\mathrm{q}}\right), 116.84\left(\mathrm{CH}_{\mathrm{Ar}}\right), 29.87\left(\mathrm{C}\left(\mathrm{CH}_{3}\right)_{3}\right), 29.24\left(\mathrm{NCH}_{3}\right), 27.40\left(\mathrm{C}\left(\mathrm{CH}_{3}\right)_{3}\right)$.

2-Benzoyl-4-methyl-1-thioxo-1,2,4,5-tetrahydro[1,2,4]triazolo[4,3-a]quinazolin-5-one (8c).

Yield 1.17 g (35\%), M.p. 194- $195^{\circ} \mathrm{C}$; Calculated for $\mathrm{C}_{17} \mathrm{H}_{12} \mathrm{~N}_{4} \mathrm{O}_{2} \mathrm{~S}$ (336.37): $60.70 \% \mathrm{C}, 3.60 \% \mathrm{H}$, $16.66 \%$ N, $9.53 \%$ S, Found: $60.59 \%$ C, 3.45\% H, 16.57\% N, 9.49\% S; FTIR, $\widetilde{v} / \mathrm{cm}^{-1}: 1693(\mathrm{C}=\mathrm{O})$, $1720(\mathrm{C}=\mathrm{O}), 2987,2955(\mathrm{CH}), 1640(\mathrm{C}=\mathrm{N}){ }^{1} \mathrm{H}-\mathrm{NMR}\left(\mathrm{CDCl}_{3}\right) \delta / \mathrm{ppm}: 10.36-10.33(1 \mathrm{H}, \mathrm{m}, \mathrm{ArH})$, 8.38-8.36 (1H, m, ArH), 7.99-7.93 (2H, m, ArH), 7.82-7.78 (1H, m, ArH), 7.66-7.46 (4H, m, ArH), $3.60\left(3 \mathrm{H}, \mathrm{s}, \mathrm{NCH}_{3}\right) ;{ }^{13} \mathrm{C}-\mathrm{NMR}\left(\mathrm{CDCl}_{3}\right) \delta / \mathrm{ppm}: 166.40(\mathrm{C}=\mathrm{O}), 165.04(\mathrm{C}=\mathrm{S}), 158.55$ (lactam $\mathrm{C}=\mathrm{O}), 142.41\left(\mathrm{C}_{\mathrm{q}}\right), 135.08\left(\mathrm{C}_{\mathrm{q}}\right), 134.76\left(\mathrm{CH}_{\mathrm{Ar}}\right), 134.01\left(\mathrm{CH}_{\mathrm{Ar}}\right), 131.98\left(\mathrm{CH}_{\mathrm{q}}\right), 131.14\left(\mathrm{CH}_{\mathrm{Ar}}\right)$, $129.46\left(\mathrm{CH}_{\mathrm{Ar}}\right), 128.57\left(\mathrm{CH}_{\mathrm{Ar}}\right), 127.92\left(\mathrm{CH}_{\mathrm{Ar}}\right), 117.09\left(\mathrm{C}_{\mathrm{q}}\right), 116.66\left(\mathrm{CH}_{\mathrm{Ar}}\right), 29.32\left(\mathrm{NCH}_{3}\right)$.

\section{References}

1. Ibrahim, I. A. M.Sc. Degree Thesis; Suez Canal University, Fac. of Science, Org. Chem. Dept. 1995.

2. Kricheldorf, H. R. Justus Liebigs Ann. Chem. 1973, 772.

3. Morley, L. J. Chem. Soc. 1956, 1103.

4. Masami, S.; Kazuya, O.; Tsutomu, F.; Shoji, W.; Takehiko, N.; Ikuo, I. J. Org. Chem. 1992, 57, 3735.

5. Russo, F.; Ghelardoni, K. Boll. Chim. Farm. 1967, 106, 826.

6. Fathalla, W.; Čajan, M.; Pazdera, P., Molecules 2000, 5, 1210.

7. Talukdar, P. B.; Sengupta, S. K.; Daha, A. K.; Roy, T. K. Ind. J. Chem. 1977, 15B, 45.

8. Fathalla, W. M.Sc. Degree Thesis; Suez Canal University, Fac. of Science, Org. Chem. Dept. 1995.

9. Fleming, I.: Frontier Orbitals and Organic Chemical Reactions; John Wiley and Sons, Inc: London, 1976. 
10. Lee, C.; Yang, W.; Parr, R. G. Phys. Rev. B 1988, 37, 785..

11. Godbout, N.; Salahub, D. R.; Andulm, J.; Wimmer, E. Can. J. Chem. 1992, 70, 560.

12. Mulliken, R. S. Chem. Phys. 1955, 23, 1833, 1841, 2338 and 2343.

13. Davidson, E. R. J. Chem. Phys. 1967, 46, 3320..

14. Foster, J. P.; Weinhold, F. J. Am. Chem. Soc. 1980, 102, 7211.

15. Reed, A. E.; Weinhold, F. J. Chem. Phys. 1983, 78, 4066.

16. Reed, A. E.; Weistock, R. B.; Weinhold, F. J. Chem. Phys. 1985, 83, 735.

17. Mayer, I. Chem. Phys. Lett. 1983, 97, 270.

18. Malkin, V. G.; Malkina, I. L.; Salahub, D. R.; Demon/1.0, A Gaussian Density Functional Program; Universite de Montreal: Montreal, 1984.

Sample Availability: Samples are available from the autors.

(C) 2001 by MDPI (http://www.mdpi.org). Reproduction is permitted for noncommercial purposes. 